\title{
Evaluation of Tp-e/QTc Ratio in Determining the Risk of Arrhythmia in Electric Shocks in Children
}

\section{Çocuk Acile Başvuran Elektrik Çarpmalarinda Aritmi Riskini Belirlemede Tp-e/QTc Süresi}

\author{
DSinem Sarı Gökay', @Şener Çınıçev' \\ 'Adana City Training and Research Hospital, Department of Pediatric Emergency, Adana, Turkey
}

\begin{abstract}
Introduction: Patients who have electrical accidents can apply to hospital with clinical signs ranging from simple skin burns to serious organ injuries. Our aim in this study is to evaluate whether QT, QTc interval and QT/QTc, Tp-e/QT, Tp-e/QTc ratios can be a marker for determine the risk of arrhythmias in children in cases of electric shock injuries that can be fatal.
\end{abstract}

Material and Method: In our study, 36 patients who were admitted to pediatric emergency with an electric shock between July 2018 and September 2019 and followed up in our clinic were included. As a control group, 25 healthy patients were included in the study. The files of the patients were examined retrospectively ECG (electrocardiogram) findings in leads DII and V5 were recorded.

Results: Thirty-six (41\%) patients who were admitted to our study due to electrical shock and followed up in our pediatric emergency were included. Sinus tachycardia was observed in two patients and no arrhythmias were detected in others. There was no statistically significant difference between the two groups between QT, QTC interval and QT/QTc, Tp-e/QT and Tp-e/QTc ratios measured in DII and V5 leads on ECG ( $p>0.05$ ). Also there was no statistically significant difference between ECG findings of genders $(p>0.05)$.

Conclusion: Electric shock can cause life-threatening situations by causing fatal arrhythmia. Although ECG findings are used to determine cardiac arrhythmia, it should be shown whether QT, QTC interval and Tp-e/QT, Tp-e/QTc ratios are significant arrhythmogenic markers by prospective studies in more specific age groups.

Keywords: Tp-e/QTc, electrical injury, children
Öz

Amaç: Elektrik kazaları basit cilt yanıklarından ciddi organ yaralanmalarına kadar değişen klinik bulgu ile gelebilmektedir. Bu çalışmadaki amacımı aritmiye neden olarak ölümcül olabilecek elektrik çarpmasına bağlı yaralanmalarda QT, QTc sürelerinin ve QT/QTc, Tp-e/QT, Tp-e/QTc oranlarının çocuklarda aritmi riskini belirleyebilecek bir belirteç olup olmadığını değerlendirmektir.

Gereç ve Yöntem: Çalışmamızda Temmuz 2018 ve Eylül 2019 tarihleri arasında elektrik çarpması şikayeti ile başvuran ve çocuk acilimizde takip edilen 36 hasta alındı. Kontrol grubu olarak da sağlıklı 25 hasta çalışmaya alındı. Hastaların dosyaları retrospektif olarak incelenerek DII ve V5 derivasyonlarında EKG (elektrokardiyogram) bulguları kaydedilmiştir.

Bulgular: Çalışmamıza elektrik çapması nedeni ile başvuran ve çocuk acilimizde takip edilen 36(\%41) hasta alındı. İki hastada sinus taşikardisi görüldü diğerlerinde aritmi saptanmadı. EKG' de DII ve V5 derivasyonlarında ölçülen QT, QTc süreleri ve QT/QTc, Tp-e/QT veTp-e/ QTc oranları arasında her iki grup arasında istatistiksel olarak anlamlı farklıık yoktu ( $p>0.05$ ).Erkek kız gruplarına bakıldığında da cinsiyet ve EKG'deki QT, QTc süreleri ve QT/QTc, Tp-e/QT ve Tp-e/QTc oranları arasında istatistiksel olarak anlamlı bir farklılık saptanmadı $(p>0.05)$

Sonuç: Elektrik çarpması malign aritmiye sebep olarak hayatı tehdit eden durumlara sebep olabilir. Kardiyak aritmiyi belirlemede EKG bulguları kullanılmakla birlikte daha çok sayıda belirli yaş gruplarında prospektif yapılacak çalışmalarla QT, QTc sürelerinin ve Tp-e/QT, Tp-e/QTc oranlarının anlamlı aritmojenik bir belirteç olup olmadığı gösterilmelidir.

Anahtar Kelimeler:Tp-e/QTc, elektrik yaralanması, çocuk 


\section{INTRODUCTION}

Injuries due to electric shock continue to be a problem for all countries in the world because of the widespread use of electricity. Although electric shock injuries occur in every group of age, they often develop as a result of home accidents in the childhood age group. Electrical accidents can come with clinical signs ranging from simple skin burns to serious organ injuries. Home accidents cause simple injuries, while high-voltage injury can result in multiple organ damage and death. ${ }^{[1,2]}$

Cardiac rhythm disturbances can occur after electric shocks, often the first few hours of admission to the hospital. Among high voltage accidents, asystole is more common in lightning shock of ventricular fibrillation. In addition, patients may have ST-T changes, supraventricular tachycardia, atrioventricular extrasystoles, right bundle branch block or complete heart block. ${ }^{[3-5]}$

Although the first serious effects on the heart occur immediately after exposure, the necessity and/or ideal followup time for post-injury monitored follow-up, especially of patients presenting with low-voltage electric shock, is controversial. ${ }^{[2,3,6,7]}$

The first thing to do to evaluate arrhythmias after electric shock is to perform ECG monitoring. In recent studies in adults, it has been shown that the Tp-e interval can be used to determine the total (transmural, apicobal and global) repolarization distribution in ECG. It is also stated that increased Tp-e interval may be a useful predictor in ventricular tachyarrhythmias and cardiovascular mortality. There are studies describing Tp-e and Tp-e/QTc rates as predictors and mortality in ventricular arrhythmias, long QT syndrome, sudden cardiac death, hypertrophic cardiomyopathy, myocardial infarction. It is also thought that the Tp-e/QT ratio may be a more accurate measurement than other heart rate-independent measurements (QT, QTc and Tp-e interval). ${ }^{[8-10]}$

In the literature, there are very few studies on the rate of Tp-e/ QTc in children, but there is no study on electric shock in children. Our aim in this study is to evaluate whether QT, QTc interval and QT/QTc, Tp-e/QT, Tp-e/QTc ratios can determine the risk of arrhythmias in children in cases of electric shock injuries that can be fatal.

\section{MATERIAL AND METHOD}

In our study, 36 patients who were admitted to Adana City Training and Research Hospital Pediatric Emergency Department between July 2018- September 2019. As a control group, 25 healthy patients were included in the study. Approval was obtained from the Adana City Training and Research Hospital Ethics Committee for the study (11-09-2019/39-551). The files of the patients were examined retrospectively and age, gender, clinical findings and physical examination findings, vital signs, treatment and results, ECG (electrocardiogram) findings, QT, QTc interval and Tp-e, Tp-e/QT and Tp-e/QTc ratios in leads DII and V5 were recorded. Patients with underlying disease and inaccurate results were excluded from the study.
The Tp-e/QT and Tp-e/QTc ratios were calculated by measuring the interval from the peak of the $T$ wave to the end of the Tp-e interval from the ECGs of the patients, measuring the QT interval from the beginning of the QRS complex to the end of the T wave, and adjusting it according to the corrected QTC Bazett formula [QTc $=$ QTd $\sqrt{ }(\mathrm{R}-\mathrm{R}$ interval)].

\section{Statistical analysis}

IBM SPSS Statistics Version 20.0 package program was used for statistical analysis of the data. Categorical measurements were summarized as numbers and percentages, while numerical measurements were summarized as mean and standard deviation, summarized as mean and standard deviation and as median and minimum-maximum where appropriate. Whether numerical measurements provide the normal distribution assumption was tested with the Kolmogorov Smirnov test. A t test was used to compare normally distributed data, and the Mann-Whitney $U$ test was used to compare data without a normal distribution. Statistical significance level was taken as 0.05 in all tests. SPSS reference: IBM Corp. Released 2011. IBM SPSS Statistics for Windows, Version 20.0. Armonk, NY: IBM Corp.

\section{RESULTS}

Thirty-six (41\%) patients who were admitted to our study due to electrical shock and followed up in our pediatric emergency department were included. The control group was 25 healthy children(59\%). The mean age of the patients was $99.17 \pm 62.03$ and the control group was $98.76 \pm 71.8$ months. The number of female patients was 11 (30.6\%) and the control group was 12 (48\%). There was no statistically significant difference between the patient and the control group in terms of age and gender $(p>0.05)$. All of the patients were followed up in the pediatric emergency observation and discharged with recovery (Table 1). All patients were monitored in the pediatric emergency service and followed up for 24 hours with hydration and symptomatic treatment, and were discharged with recovery. Two patients had sinus tachycardia and other patients had no arrhythmia.

\begin{tabular}{lcc}
\hline Table 1. Epidemiological features of patients & & \\
& $\begin{array}{c}\text { Patients } \\
\text { (n:36) (\%) }\end{array}$ & $\begin{array}{c}\text { Control } \\
\text { (n:25) (\%) }\end{array}$ \\
\hline Gender & $11(30.6)$ & $12(48)$ \\
$\quad$ Girl & $25(69.4)$ & $13(52)$ \\
Boy & $99.17 \pm 62.03$ & $98.76 \pm 71.83$ \\
Age (Months) & & \\
Clinic & $13(36.1)$ \\
$\quad$ No symptoms & $19(52.8)$ \\
$\quad$ Burned limbs & $4(11.1)$ \\
$\quad$ Burn + Central nervous system symptoms & $2(5.5)$ \\
$\quad$ Cardiovascular system symptoms & \\
Treatment & $36(100)$ \\
$\quad$ Hydration & $36(100)$ \\
$\quad$ Observation & $19(52.7 \%)$ \\
$\quad$ Other & & \\
Hospitalization & $36(100)$ \\
$\quad$ Pediatric Emergency Service & \\
Result & $36(100)$ \\
$\quad$ Recovery & $0(0)$ \\
$\quad$ Exitus &
\end{tabular}


The laboratory values in the patient group were CK 209 (763971), CK-MB 4.35 (1.1-107) ng/mL and troponin values were $2(0-6) \mathrm{ng} / \mathrm{mL}$. Other laboratory values of the patients are summarized in Table 2.

Table 2. Laboratory results of patients presenting with electric shock

\begin{tabular}{lc} 
& Patient (n:36) median (min-max) \\
\hline WBC $\left(10^{3} \mu \mathrm{L}\right)$ & $9.4(4.1-16.5)$ \\
Hemoglobin $(\mathrm{g} / \mathrm{dL})$ & $12.6(9-16.3)$ \\
Hematocrit $(\%)$ & $36.4(29.3-46.4)$ \\
Platelets $\left(10^{3} \mu \mathrm{L}\right)$ & $306(207-584)$ \\
Glucose $(\mathrm{mg} / \mathrm{dL})$ & $100(11-168)$ \\
BUN $(\mathrm{mg} / \mathrm{dL})$ & $23(11-38)$ \\
Creatinine $(\mathrm{mg} / \mathrm{dL})$ & $0.36(0.2-1)$ \\
SGOT$(\mathrm{U} / \mathrm{L})$ & $33.3(19-94)$ \\
SGPT $(\mathrm{U} / \mathrm{L})$ & $15.15(5-32)$ \\
Sodium $(\mathrm{mmol} / \mathrm{L})$ & $138(134-141)$ \\
Potassium $(\mathrm{mmol} / \mathrm{L})$ & $4(3.2-4.8)$ \\
Calcium $(\mathrm{mg} / \mathrm{dL})$ & $9.8(8.3-10.7)$ \\
CK & $209(76-3971)$ \\
CK-MB $(\mathrm{ng} / \mathrm{mL})$ & $4.35(1.1-107)$ \\
Troponin-l $(\mathrm{ng} / \mathrm{mL})$ & $2(0-6)$ \\
\hline
\end{tabular}

In ECG of patients in DII derivation; QT interval $0.31 \pm 0.03 \mathrm{~s}$, QTc interval $0.40 \pm 0.02 \mathrm{~s}$, QT/QTc interval $0.78 \pm 0.08$, Tp-e/ QT interval $0.22 \pm 0,04$ and Tp-e/QTC ratio was $0.18 \pm 0.03$. In ECG of control group in DII derivation; QT interval 0.30 \pm 0.04 s, QTc interval $0.40 \pm 0.03 \mathrm{~s}$, QT/QTc ratio $0.76 \pm 0.09$, Tp-e/QT ratio $0.22 \pm 0.04$ and $\mathrm{Tp}$-e/QTc ratio was $0.16 \pm 0.03$. In the ECG of patients, in the $\mathrm{V} 5$ derivation the QT interval was $0.31 \pm 0.03$ s, QTc interval $0.40 \pm 0.03 \mathrm{~s}$, QT/QTc ratio $0.79 \pm 0.08$, Tp-e/QT ratio $0.23 \pm 0.04$ and Tp-e/QTc ratio $0.18 \pm 0.03$. In ECG of control group in V5 derivation QT interval was $0.30 \pm 0.03 \mathrm{~s}$, QTc interval $0.39 \pm 0.02 \mathrm{~s}$, QT/QTc ratio $0.76 \pm 0.09$, Tp-e/QT ratio $0.24 \pm 0.04$ and $\mathrm{Tp}$-e/QTc ratio $0.17 \pm 0.02$. There was no statistically significant difference between the two groups in the time measured in leads DII and V5 on the ECG ( $p>0.05$ ) (Table 3). There was no statistically significant difference between QT, QTc interval, QT/QTc, Tp-e/QT and Tp-e/QTc ratio and gender (p>0.05) (Table 4).

\begin{tabular}{lccc}
\multicolumn{4}{l}{ Table 3. Comparison of electrocardiographic results } \\
ECG & Patient (mean \pm SD) & Control & p \\
\hline QT DII (s) & $0.31 \pm 0.03$ & $0.30 \pm 0.04$ & 0.396 \\
QTc DII (s) & $0.40 \pm 0.02$ & $0.40 \pm 0.03$ & 0.956 \\
QT/QTc (s) & $0,78 \pm 0.08$ & $0.76 \pm 0.09$ & 0.323 \\
Tp-e/QT DII & $0.22 \pm 0.04$ & $0.22 \pm 0.04$ & 0.540 \\
Tp-e/QTc DII & $0.18 \pm 0.03$ & $0.16 \pm 0.03$ & 0.130 \\
QT V5 (s) & $0.31 \pm 0.03$ & $0.30 \pm 0.03$ & 0.186 \\
QTc V5 (s) & $0.40 \pm 0.03$ & $0.39 \pm 0.02$ & 0.794 \\
QT/QTcV5 (s) & $0,79 \pm 0.08$ & $0,76 \pm 0.09$ & 0.157 \\
Tp-e/QT V5 & $0.23 \pm 0.04$ & $0.24 \pm 0.04$ & 0.457 \\
Tp-e/QTc V5 & $0.18 \pm 0.03$ & $0.17 \pm 0.02$ & 0.380 \\
\hline
\end{tabular}

Table 4. Comparison of electrocardiography results by gender groups

\begin{tabular}{lccc} 
ECG & Female $(\mathbf{m e a n} \pm$ SD) & Male & $\mathbf{p}$ \\
\hline QT DII (s) & $0.31 \pm 0.04$ & $0.31 \pm 0.03$ & 0.728 \\
QTc DII (s) & $0.40 \pm 0.02$ & $0.40 \pm 0.02$ & 0.990 \\
QT/QTc (s) & $0.77 \pm 0.09$ & $0.77 \pm 0.08$ & 0.899 \\
Tp-e/QT DII & $0.22 \pm 0.04$ & $0.22 \pm 0.04$ & 0.298 \\
Tp-e/QTc DII & $0.17 \pm 0.03$ & $0.17 \pm 0.03$ & 0.260 \\
QT V5 (s) & $0.31 \pm 0.03$ & $0.31 \pm 0.03$ & 0.923 \\
QTc V5 (s) & $0.39 \pm 0.02$ & $0.40 \pm 0.03$ & 0.184 \\
QT/QTcV5 (s) & $0.78 \pm 0.09$ & $0.78 \pm 0.09$ & 0.775 \\
Tp-e/QT V5 & $0.23 \pm 0.04$ & $0.23 \pm 0.04$ & 0.749 \\
Tp-e/QTc V5 & $0.18 \pm 0.03$ & $0.18 \pm 0.03$ & 0.803 \\
\hline
\end{tabular}

\section{DISCUSSION}

Electric shock is rare but important because of its very serious vital effects. ${ }^{[1]}$ Mortality rate due to electric shock, especially cardiac arrest and arrhythmias, is 3-15\%.[12-14] Although electric shock is a high risk for arrhythmia, arrhythmic complications due to the low number of cases in studies; guidelines on evaluation and treatment contain limited information. ${ }^{[2]}$ Ventricular fibrillation, which is fatal at the time of electric shock, may develop, and the most common arrhythmias at the time of admission to the hospital after electric shock are sinus tachycardia, bradycardia, and atrialventricular arrhythmias. ${ }^{[1,15]}$

The effect of electrical injury on myocardial cells and its electrocardiographic effects are unclear. Although the pathogenesis of cardiac effects is not fully understood, it is thought to be multifactorial. In electrical injury, primarily the electrical pathway in the heart and ion channels are affected. Therefore, complications of arrhythmia can be detected before myocardial damage occurs. It is stated in the literature that ECG changes occur at lower currents. ${ }^{[16-18]}$

Gokdemir et al. detected the sinus tachycardia as the most common arrhythmia in their studies on 36 patients with low voltage electric shocks and reported that they did not develop secondary arrhythmia in their patients. ${ }^{[19]}$ In their study, Kramer et al. ${ }^{[15]}$ detected arrhythmia in $7 \%$ of 84 patients aged 0-17. Celik et al. ${ }^{[20]}$ followed 24-hour cardiac monitoring during their study with 38 patients and Bailey et al. ${ }^{[21]}$ in their study with 141 patients, they showed that secondary arrhythmia did not develop. In the study in which Claudet et al. evaluated 48 pediatric patients with low voltage, 8 patients had sinus tachycardia, right bundle branch block and t wave changes in ECG. ${ }^{[6]}$ ECG findings improved in all patients and no late arrhythmia was detected. Pawlik et al. did not encounter malignant arrhythmia in their study and their mortality was $0 \% .{ }^{[22]}$ Searle et al. In their study, they did not detect $0 \%$ mortality and life-threatening arrhythmia in their studies. ${ }^{[1]}$ Similar to the literature in our study, sinus tachycardia was observed in 2 of our patients, malignant arrhythmia was not observed in other patients during the observation and all our patients were discharged with recovery. 
Electrocardiography is an important diagnostic tool for detecting arrhythmias. While it is necessary to evaluate with ECG in patients with electric shock, the effects of electric shock on ECG parameters have not been investigated in the literature. ${ }^{[16]}$

There are studies in the literature showing that QTc, Tp-e interval and Tp-e/QT and Tp-e/QTc ratios are arrhythmogenic markers associated with cardiovascular mortality and morbidity. ${ }^{[23]}$ Although studies in the literature in children are limited, there are no studies on Tp-e and Tp-e/QT interval in ECG related to electric shock in children. Karataş et al. in their study of electric shock in adults, QTc, QTD, Tp-e interval, Tp-e/QT ratio and Tp-e/QTc ratio were significantly longer compared to patients' admission and control ECGs. [16]

Türe et al. ${ }^{[23]}$ In their study with children who had dilated cardiomyopathy and exitus, they found a statistically significant difference in QT, QTc and Tp-e interval. In studies on mitral valve prolapse and ECG findings in children, the interval of QT, QTc, Tp-e and the ratios of Tp-e/QT and Tp-e/ QTc were significantly increased. ${ }^{[23]}$ Turker et al. ${ }^{[25]}$ did not detect a significant difference in QT and QTc interval in mitral valve prolapsus patients with ventricular arrhythmia. In our study, we used the ECG findings in leads DII and V5, as the left precordial leads were shown to reflect the best values in demonstrating transmural repolarization. ${ }^{[26]}$ In our study, there were no statistically significant differences between ECG and QT, QTc interval, QT/QTc, Tp-e/QT and Tp-e/QTc ratios measured in DII and V5 leads ( $p>0.05)$. There was no statistically significant difference between QT, QTc interval, QT/QTc, Tp-e/QT and Tp-e/QTc ratios by gender ( $p>0.05)$. We think that we did not find a significant difference in terms of time, since the number of patients was low, the control ECG of the patient group was not included in the study, and the patient age distribution was in a wide range such as 0-18 years.

Electric shock is generally more common in children and boys in the form of home accidents. ${ }^{[6,19]}$ In our study, the average age of our patients was $99.17 \pm 62.03$ months, and similar to the literature, electric shock was more common in male.

Recent studies of electrical burns in children have shown that creatine kinase and CK-MB are a weak marker in demonstrating myocardial damage, and therefore these studies have suggested that they should not be used to show cardiac damage caused by electric shock. The effectiveness of the height of the troponin level in showing myocardial damage due to electric shock is uncertain. ${ }^{[20,22,27]}$ Pilecky et al. in their study, they observed that troponin and CK-MB were not useful in risk assessment after electrical shock. Similarly, in our study, no significant high values were found in CK, CKMB and troponin values. ${ }^{[2]}$

\section{CONCLUSION}

As a result, electric shock can cause life-threatening situations by causing arrhythmia. There are limited reports of arrhythmias due to electric shock in children in the literature. Although ECG findings are used in determining cardiac arrhythmia, it should be shown whether QT, QTc, Tp-e interval and Tp-e/QT, Tp-e/QTc ratios are significant arrhythmogenic markers with more prospective studies in certain age groups.

\section{ETHICAL DECLARATIONS}

Ethics Committee Approval: Approval was obtained from the Adana City Training and Research Hospital Ethics Committee for the study (11-09-2019/39-551).

Informed Consent: Written consent was obtained from all patients who participated in the study and their relatives.

Referee Evaluation Process: Externally peer-reviewed.

Conflict of Interest Statement: The author(s) declared no potential conflicts of interest with respect to the research, authorship, and/or publication of this article.

Financial Disclosure: The author(s) received no financial support for the research, authorship, and/or publication of this article.

Author Contributions: Ş.Ç. contributed to study concept and design of the study. S.S.G. and Ş.Ç contributed to analysis and interpretation of the data. S.S.G. and Ş.Ç. contributed to drafting of the manuscript.

Availability of Data and Materials: All materials taken from other sources (including our own published writing) were clearly cited.

Human Rights: Our work does not infringe on any rights of others, including privacy rights, and intellectual property rights. There is no human rights violation in our manuscript.

\section{REFERENCES}

1. Searle J, Slagman A, Maass W, Mockel M. Cardiac monitoring in patients with electrical injuries. An analysis of 268 patients at the Charite Hospital. Dtsch Arztebl Int 2013;110(50):847-53.

2. Pilecky D, Vamos M, Bogyi P, Muk B et al. Risk of cardiac arrhythmias after electrical accident: a single-center study of 480 patients. Clin Res Cardiol 2019;108(8):901-8. doi: 10.1007/s00392-019-01420-2.

3. Haim A, Zucker N, Levitas A, Sofer S, Katz A, Zalzstein E. Cardiac manifestations following electrocution in children. Cardiol Young 2008;18(5):458-60.

4. McLeod JS, Maringo AE, Doyle PJ, Vitale $L$ et al. Analysis of Electrocardiograms Associated with Pediatric Electrical Burns. J Burn Care Res 2018;39(1):65-72.

5. Vural A, Sarak T, Vural S, Yastı AÇ. The importance of electrocardiography in the clinical course of electric injuries Ulus Travma Acil Cerrahi Derg. 2015;21(3):216-9.

6. Claudet I, Maréchal C, Debuisson C, Salanne S. Risk of arrhythmia an domestic low-voltage electrical injury. Arch Pediatr. 2010;17(4):343-9.

7. Bailey B, Gaudreault P, Thivierge RL. Cardiac monitoring of high-risk patients after an electrical injury: a prospective multicentre study. Emerg Med J 2007;24(5):348-52. 
8. Smetana $P$, Schmidt $A$, Zabel $M$, Hnatkova $K$ et al. Assessment of repolarization heterogeneity for prediction of mortality in cardiovascular disease: peak to the end of the $\mathrm{T}$ wave interval and nondipolar repolarization components. J. Electrocardiol 2011;44:30-8.

9. Zhao X, Xie Z, Chu Y et al. Association between Tp-e/QT ratio and prognosis in patients undergoing primary percutaneous coronary intervention for ST-segment elevation myocardial infarction. Clin Cardiol 2012;35:559-64.

10. Avcı A,Acehan S, Avcı SB, Gulen M,Bulut A,Satar S. QTc, Tp-e interval and Tp-e/QTc ratio in patients with nontraumatic subarachnoid hemorrhage. Am J Emerg Med 2020;14. DOl:https://doi.org/10.1016/j.ajem.2017.

11. Dokov W, Dokova K.Epidemiology and diagnostic problems of electrical injury in forensic medicine. Forensic Med 2010;126-35.

12. Akkas M, Hocagil H, Didem A, Bulent E, Mahir KM, Mahir OM. Cardiac monitorization in patients with electrocution injury. Ulus Travma Acil Cerrahi Derg 2012;18(4):301-5.

13. Arnoldo BD, Purdue GF, Kowalske K, Helm PA, Burris A, Hunt JL.Electrical injuries: a 20-Year review.J Burn Care Rehabil 2004;25(6):479-84.

14. Soar J, Perkins GD, Abbas G, et al. European Resuscitation Council Guidelines for Resuscitation 2010 Section 8. Cardiac arrest in special circumstances: electrolyte abnormalities, poisoning, drowning, accidental hypothermia, hyperthermia, asthma, anaphylaxis, cardiac surgery, trauma, pregnancy, electrocution. Resuscitation 2010; 81(10):1400-33.

15. Krämer C, Pfister R, Boekels T, Michels G.Cardiac monitoring always required after electrical injuries? Medizinische Klin 2010;111(8):708-14.

16. Karataş MB, Onuk T, Güngör B, İpek G, Özcan KS. Assessment of electrocardiographic parameters in patients with electrocution injury.J Electrocardiol. 2015;48(5):809-14.

17. Vural A, Sara T, Vural S, Yastı AÇ. The importance of electrocardiography in the clinical course of electric injuries Ulus Travma Acil Cerrahi Derg. 2015;21:3.

18. Koumbourlis AC. Electrical injuries. Crit Care Med 2002;30:424-30.

19. Gokdemir MT, Kaya H, Söğüt O, Cevik M.Factors affecting the clinical outcome of low-voltage electrical injuries in children. Pediatr Emerg Care 2013;29(3):357-9.

20. Bailey B, Forget S, Gaudreault P.Prevalence of potential risk factors in victims of electrocution. Forensic Sci Int 2001;123(1):58-62.

21. Çelik A, Ergün O, Özok G . Pediatric electrical injuries: a review of 38 consecutive patients. J Pediatr Surg 2004;39(8):1233-7.

22. Pawlik AM, Lampart A, Stephan FP, Bingisser R, Ummenhofer W, Nickel CH. Outcomes of electrical injuries in the emergency department: a 10-year retrospective study. Eur J Emerg Med 2016;23(6):448-54.

23. Türe $M$, Balık $H$, Akın A, Bilici $M$, Nergiz A.The relationship between electrocardiographic data and mortality in children diagnosed with dilated cardiomyopathy. Eur J Pediatr. 2020. doi: 10.1007/s00431-02003569-9.

24. Demirol M, Karadeniz C, Ozdemir R, Çoban Ş, Katipoğlu N, Yozgat Y, Meşe $\mathrm{T}$, Unal N. Prolonged Tp-e Interval and Tp-e/QT Ratio in Children with Mitral Valve Prolapse. Pediatr Cardiol 2016;37(6):1169-74.

25. Turker Y, Ozaydin M, Acar G, et al.Predictors of ventricular arrhythmias in patients with mitral valve prolapse. Int J Cardiovasc Imaging. 2010;26(2):139-45.

26. Antzelevitch C, Fish J. Electrical heterogeneity within the ventricular wall. Basic Res Cardiol 2001;96:517-27

27. McLeod JS, Maringo AE, Doyle PJ, et al. Analysis of Electrocardiograms Associated with Pediatric Electrical Burns. J Burn Care Res 2018;1;39(1):6572. 